\title{
FAKTOR DETERMINAN YANG BERHUBUNGAN DENGAN KEJADIAN ANEMIA PADA REMAJA PUTRI DI SMP LUBUKPAKAM
}

\author{
Zuraidah Nasution ${ }^{l}$ Ida Nurhayati ${ }^{2}$ Ade Indah Dwicahyu ${ }^{3}$ \\ Poltekkes Kemenkes Medan ${ }^{123}$ \\ Email: ${ }^{1}$ zn.poltekkesmedan@gmail.com
}

\begin{abstract}
Based on results of preliminary research in junior high school at Lubuk Pakam, shows that $25.7 \%$ of girls aged 13-14 years were anemic, while in the data of the Indonesia Ministry of Health in 2014 there were 18.4\% of adolescents had anemia. Anemia in adolescents especially students will lead into fatigueness, and weakening of brain cell activity thereby reducing concentration and their learning achievement. Furthermore, teenage girls who are anemic have a high risk of developing various dangerous conditions in their adulthood such as anemia during pregnancy, low birth weight, bleeding that can threaten the safety of mothers and their babies. Babies born with a low body weight will experience metabolic growth disorders like IQ below the normal range. Then the baby will grow into anemic toddler and furtheremore into adolescents with iron deficiency. This cycle will harm the country and hamper national development goals. The study was conducted on 116 girls of junior high school student at LubukPakam using cross-sectional designs. Data were collected through interviews, food recall, measurement and observation, and analyzed using multiple logistic regression. The purpose of this study was to determine the determinant factors associated with the incidence of anemia in girls students of junior high school students at LubukPakam. The results of the study concluded that the most dominant factors affecting the incidence of anemia in girls of junior high school students were the average intake of vitamin B12 and nutritional knowledge. Good intake of vitamin $B_{12}$, and good nutritional knowledge are consecutively 2,04 times and 1.65 times reducing the incidence of anemia in adolescent girls.
\end{abstract}

Keywords: anemia in adolescent, vitamin B12 intake, nutritional knowledge

\begin{abstract}
ABSTRAK
Berdasarkan hasil penelitian pendahuluan di Sekolah Menengah Pertama (SMP) Negeri Lubuk Pakam, remaja putri usia 13-14 tahun yang mengalami anemia terdapat sebanyak $25,7 \%$, sedangkan pada data Kemenkes RI 2014 terdapat 18,4\% remaja yang mengalami anemia. Anemia pada remaja yang sedang bersekolah akan dapat menimbulkan dampak berupa: lelah, letih dan lesu dan melemahnya aktivitas sel otak sehingga menurunkan konsentrasi dan prestasi belajar. Selanjutnya seorang remaja putri yang mengalami anemia akan menimbulkan dampak yang sangat berbahaya dan merugikan diantaranya cenderung anemia pada saat hamil, melahirkan bayi dengan berat lahir rendah, perdarahan yang dapat mengancam keselamatanbayi dan ibunya. Bayi yang lahir dengan berat badan yang rendah akan mengalami gangguan pertumbuhan metabolisme seperti IQ dibawah ambang batas normal. Kemudian bayi tersebut akan tumbuh menjadi balita anemia yang jika tidak juga di tanggulangi dan akan kembali tumbuh menjadi remaja yang defiseinsi zat besi kembali. Kondisi ini akan merugikan negara dan menghambat tujuan pembangunan nasional. Penelitian dilakukan pada remaja putri siswa di SMP Negeri LubukPakam sebanyak 116 orang. menggunakan desain crossectional. Data dikumpulkan melalui wawancara, food recall, pengukuran serta observasi, dan dianalisis menggunakan regresi logistic berganda. Tujuan penelitian untuk mengetahui faktor determinan yang berhubungan dengan kejadian anemia pada remaja putri siswa SMP Negeri Lubuk Pakam. Hasil penelitian menyimpulkan bahwa faktor yang paling dominan memengaruhi kejadian anemia pada remaja puteri SMP adalah rata-rata asupan vitamin B12 dan skor pengetahuan gizi. Asupan vitamin B12 serta pengetahuan gizi yang baik dapat masing-masing 2,04 kali dan 1,65 kali menurunkan kejadian anemia pada remaja puteri.
\end{abstract}

Kata Kunci: anemia remaja putri, asupan vitamin B12, pengetahuan gizi 


\section{PENDAHULUAN \\ Latar Belakang}

Anemia merupakan masalah gizi yang paling sering dijumpai di dunia, terutama di Negara berkembang. Remaja salah satu kelompok yang rawan menderita anemia, karena masa remaja adalah masa peralihan dari masa anak-anak ke masa dewasa atau disebut juga masa pubertas. Pada masa pubertas ini terjadi pertumbuhan dan perkembangan yang pesat sehingga membutuhkan zat-zat gizi yang relative besar jumlahnya. Menurut data Kemenkes RI 2014 terdapat 18,4\% pada kelompok umur 15-24 tahun yang mengalami anemia. Berdasarkan hasil penelitian awal, diketahui bahwa di SMP Negeri Lubuk Pakam terdapat sebanyak 25,7\% siswi yang mengalami anemia. Hal ini menunjukkan data prevalensi anemia pada siswi di SMP Negeri sudah mengkhawatirkan karena angka yang lebih tinggi dari angka nasional.

Faktor resiko anemia pada remaja putri yaitu kehilangan darah secara kronis akibat menstruasi, asupan zat besi yang tidak cukup, penyerapan zat besi yang buruk, infeksi cacing, penyakit kronis, serta kekurangan zat gizi lainnya seperti vitamin $\mathrm{C}$, vitamin $\mathrm{B}_{12}$ dan asam folat. Kejadian anemia pada remaja disebabkan asupan gizi yang kurang yang umumnya disebabkan karena kurangnya pengetahuan.

Remaja yang anemia akan dapat memberikan dampak berupa: lelah, letih dan lesu dan melemahnya aktivitas sel otak sehingga menurunkan konsentrasi dan prestasi belajar. Selanjutnya seorang remaja putri yang mengalami anemia akan menimbulkan dampak yang sangat berbahaya dan merugikan diantaranya cenderung mengalami anemia pada saat hamil sehingga cenderung melahirkan bayi dengan berat lahir rendah, mengalami perdarahan yang dapat mengancam keselamatan jiwa bayi dan ibunya serta menigkatkan angka kematian ibu dan bayi. Bayi yang lahir dengan berat badan yang rendah akan mengalami gangguan pertumbuhan metabolisme seperti IQ dibawah ambang batas normal. Kemudian bayi tersebut akan tumbuh menjadi balita anemia yang jika tidak juga di tanggulangi dan akan kembali tumbuh menjadi remaja yang defiseinsi zat besi kembali. Hal ini akan menghambat pencapaian tujuan pembangunan kesehatan dan pembangunan nasional. Oleh karena itu perlu dilakukan penelitian untuk mengetahui faktor determinan yang berhubungan dengan kejadian anemia pada remaja putri. Asupan vitamin B12 yang baik dapat menghindarkan remaja untuk mengalami anemia (Aryani,2010; Briawan, 2014; Dewi, 2018).

Anemia adalah suatu keadaan ketika kadar hemoglobin $(\mathrm{Hb})$ dalam darah berkurang dari normal, lebih rendah dari normal. Adapun kadar $\mathrm{Hb}$ normal pada kelompok remaja adalah12 gr \% (WHO, 2010).

Remaja adalah seseorang yangberada dalam rentang umur 10 sampai 19 tahun baik belum maupun sudah menikah. Terdapat sekitar 1,2 miliar remaja di dunia yaitu sama dengan seperlima dari populasi dunia (WHO, 2010). Remaja merupakan aset bangsa untuk terciptanya generasi penerus yang baik.Masa remaja (adoslescence) merupakan masa pertumbuhan dan perkembangan ditandai dengan terjadinya perubahan yang sangat cepat secara fisik, psikis, dan kognitif.. Kelompok umur ini sangat rawan menderita anemia karena bersamaan dengan menstruasi yang mengeluarkan zat besi yang diperlukan untuk pembentukan hemoglobin juga akibat percepatan pertumbuhan dan peningkatana aktivitas fisik yang dilakukan (Sirajudin, 2014).

Masa remaja juga merupakan tahapan kritis kehidupan, sehingga periode tersebut dikategorikan sebagai kelompok rawan, dan mempunyai risiko kesehatan tinggi. Akan tetapi remaja sering kurang mendapatkan perhatian dalam program pelayanan kesehatan. Padahal kenyataannya, banyak kasus kesehatan saat dewasa ditentukan oleh kebiasaan hidup sehat sejak usia remaja (Briawan, 2014; Ali K).

Pada masa ini terjadi peningkatan kebutuhan zat besi akibat adanya pertumbuhan dan menstruasi. Aktifitas sekolah, maupun berbagai aktifitas yang tinggi akan berdampak pada pola makan yang tidak teratur, selain itu kebiasaan mengkonsumsi minuman yang menghambat absorbsi zat besi akan mempengaruhi kadar hemoglobin seseorang (Ani Seri Luh, 2010; Adriani,2012; Almatsier,2016.

Penyebab anemia pada remaja putri umumnya karena defisiensi zat besi akibat kurangnya pengetahuan gizi. Pengetahuan yang baik akan mendorong seseorang untuk menampilkan sikap yang sesuai dengan pengetahuan. Walaupun sikap merupakan suatu pandangan yang berbeda dengan suatu pengetahuan yang dimiliki seseorang, namun 
apabila seseorang telah mendengar tentang anemia maka pengetahuan ini akan membawa seseorang untuk berfikir dan berusaha untuk mencegah agar tidak terkena anemia (Notoatmodjo, 2010). Sedangkan menurut Fikawati (2017), anemia pada remaja dapat disebabkan oleh kurangnya asupan hgizi,. Kehamilan masa remaja serta penyakit infeksi dan social ekonomi

Menurut MOST USAID Micronutrient Program dalam Briawan (2014) Anemia yang paling sering terjadi yang disebabkan oleh :

- Rendahnya asupan zat besi dan zat gizi lainnya, yang disebabkan karena rendahnya konsumsi pangan sumber zat besi. Zat gizi lain yang menyebabkan terjadinya anemia karena kekurangan vitamin $\mathrm{C}, \mathrm{B}_{12}$ dan asam folat

- Penyerapan zat besi yang rendah yang disebabkan karena adanya komponen penghambat di dalam makanan seperti, fitat. Rendahnya zat besi pada makanan nabati maka akan menyebabkan zat besi tidak dapat di resap dan digunakan pada tubuh.

Beberapa senyawa yang dapat menghambat penyerapan zat besi diantaranya teh, kopi sertabeberapa sayuran dan buah yang mengandung tannin yang memiliki efek mengikat zat besi sehingga zat besi susah dicerna dan akhirnya terbuang melalui keringat dan urin. Sebaliknya vitamin $\mathrm{C}, \mathrm{B}_{12}$ dan asam folat membantu penyerapan zat besi dalam tubuh dengan membuat kondisi lambung menjadi asam sehingga proses perubahan zat besi dari bentuk ferri menjadi ferro menjadi lebih optimal. Adapun kebutuhan remaja usia 13-15 tahun untuk vitamin $\mathrm{C}=65 \mathrm{mg}$ /hari vitamin $\mathrm{B}_{12}$ adalah 2,4 $\mathrm{mcg} / \mathrm{hari}$ dan asam folat $=400 \mathrm{mcg} / \mathrm{hari}$ (Almatsier, 2016; Supariasa,2016).

\section{TUJUAN PENELITIAN}

Adapun yang menjadi tujuan penelitian ini adalah untuk mengetahui faktor determinan yang berhubungan dengan kejadian anemia pada remaja putri.

\section{METODE}

Penelitian adalah observasional dengan rancangan crossectional. Lokasi penelitian adalah SMP Negeri 8 Lubuk Pakam yang dipilih dengan pertimbangan: bahwa sekolah tersebut memiliki angka prevalensi anemia yang tinggi pada remaja putri dibandingkan angka nasional (Kemenkes, 2014), serta adanya permintaan pihak sekolah untuk ilmu kesehatan yang bermanfaat bagi remaja.

Adapun variable independen yang diteliti adalah: tingkat pengetahuan, sikap, tindakan, status gizi, asupan protein, asupan vitamin C, asupan vitamin $\mathrm{B}_{12}$, asupan asam folat. Populasi dalam penelitian ini adalah 140 orang, dan sampel yang memenuhi persyaratan yaitu 116 orang (Rachmat, 2016). Adapun kriteria sampel yaitu: bersedia menjadi sampel yang dibuktikan dengan penandatanganan inform consent serta tidak dalam keadaan menstruasi. Pengumpulan data dilakukan secara langsung melalui: wawancara, food recall 24 jam selama 3 (tiga) hari tidak berturut-turut untuk asupan gizi, pengukuran berat badan dengan bathroom scale, tinggi badan dengan microtoise serta pengukuran kadar hemoglobin menggunakan easy touch dan observasi (Saryono, 2013; Wawan, 2010).

\section{HASIL}

Hasil analisis univariat, menunjukkan bahwa ummnya $(60,3 \%)$ remaja putri di SMP Negeri di Lubuk Pakam sudah sudah berada dalam kondisi yang tidak anemia (Tabel 1).

Tabel 1

\section{Distribusi Responden Berdasarkan Variabel dan Kategori Kadar Hb Remaja Puteri SMP}

\begin{tabular}{lcc}
\hline Variabel & \multicolumn{2}{c}{ Jumlah } \\
\cline { 2 - 3 } & $\mathrm{n}$ & $\mathrm{f}(\%)$ \\
\hline Kadar Hemoglobin & & \\
Anemia & 46 & 39,7 \\
Tidak Anemia & 70 & 60,3 \\
\hline
\end{tabular}

Umumnya remaja putri masih memliki pengetahuan dan tindakan yang kurang baik walaupun sudah memiliki sikap yang sudah baik (Tabel 2).

Tabel 2

Distribusi Responden Berdasarkan Kategori Pengetahuan, Sikap dan Tindakan Remaja Puteri SMP

\begin{tabular}{lcc}
\hline No $\quad$ Variabel & \multicolumn{2}{c}{ Jumlah } \\
\cline { 2 - 3 } & $\mathrm{n}$ & $\mathrm{f}(\%)$ \\
\hline 1. Tingkat Pengetahuan & & \\
Kurang Baik & 61 & 52,6 \\
Baik & 55 & 47,4 \\
2. Sikap & & \\
$\quad$ Kurang Baik & 56 & 48,3 \\
$\quad$ Baik & 60 & 51,7 \\
3. Tindakan & & \\
$\quad$ Kurang Baik & 64 & 56,2 \\
$\quad$ Baik & 52 & 44,8 \\
\hline
\end{tabular}

Asupan protein, vitamin $\mathrm{C}$ dan asam folat sebaian besar masih dalam kondisi kurang baik, walaupun untuk asupan vitamin B12 sudah terpenuhi.

Tabel 3 
Distribusi Responden Berdasarkan Kategori Asupan Protein, Vitamin C, Vitamin B12, dan Asam Folat Remaja Puteri SMP

\begin{tabular}{lcc}
\hline No Variabel & \multicolumn{2}{c}{ Jumlah } \\
\cline { 2 - 3 } & $\mathrm{n}$ & $\mathrm{f}(\%)$ \\
\hline 1. Asupan Protein & & \\
$\quad$ Kurang Baik & 62 & 53,4 \\
$\quad$ Baik & 54 & 46,6 \\
2. Asupan Vitamin C & & \\
$\quad$ Kurang & 62 & 53,4 \\
$\quad$ Baik & 54 & 46,6 \\
3. Asupan Vitamin $\mathrm{B}_{12}$ & & \\
$\quad$ Kurang & 30 & 25,9 \\
$\quad$ Baik & 86 & 74,1 \\
4. Asupan Asam Folat & & \\
$\quad$ Kurang & 104 & 89,7 \\
\hline
\end{tabular}

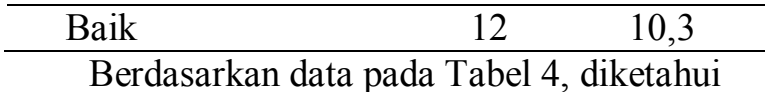
bahwa hanya $38 \%$ remaja putri yang memiliki status gizi yang baik, sedangkan 48,2\% dengan status gizi kurang sedangkan 14,7\% lainnya berada dalam status gizi gemuk dan obesitas.

Tabel 4

Distribusi Responden Berdasarkan Kategori Status Gizi melalui Indeks Massa Tubuh (IMT) Remaja Puteri SMP

\begin{tabular}{lcc}
\hline No Kategori IMT & \multicolumn{2}{c}{ Jumlah } \\
\cline { 2 - 3 } & $\mathrm{n}$ & $\mathrm{f}(\%)$ \\
\hline Kurus & 56 & 48,2 \\
Normal & 44 & 38,0 \\
Gemuk & 10 & 9,5 \\
Obesitas & 6 & 5,2 \\
\hline
\end{tabular}

Terdapat hubungan yang signifikan antara variable independen dengan dependen untuk beberapa variable (Tabel 5).

Tabel 5

Hasil Analisis Bivariat Variabel Independen dengan Kategori Hb

\begin{tabular}{llcc}
\hline No & Variabel & p_value & Keterangan \\
\hline 1 & Status Gizi & 0,049 & Signifikan \\
2 & Kategori Pengetahuan & 0,003 & Signifikan \\
3 & Kategori Sikap & 0,028 & Signifikan \\
4 & Kategori Asupan Vit-B12 & 0,008 & Signifikan \\
5 & Rata-rata Skor Pengetahuan & 0,001 & Signifikan \\
6 & Rata-rata Skor Sikap & 0.008 & Signifikan \\
7 & Rata-rata Skor Asupan Vit-B12 & 0,008 & Signifikan \\
\hline
\end{tabular}

Selanjutnya berdasarkan hasil analisis multivariate (Tabel 6) dapat diketahui bahwa variable yang sanga memengaruhi kejadian anemia pada remaja putri di SMP Negeri Lubuk Pakam adalah ratarata asupan vitamin B12 dan tingkat pengetahuan gizi nya.

Tabel 5

Hasil Analisis Multivariat

\begin{tabular}{|c|c|c|c|c|c|c|c|c|}
\hline \multirow[t]{2}{*}{ Variabel } & \multirow[t]{2}{*}{ B } & \multirow[t]{2}{*}{ S.E. } & \multirow[t]{2}{*}{ Wald } & \multirow[t]{2}{*}{$\mathrm{df}$} & \multirow[t]{2}{*}{ Sig. } & \multirow[t]{2}{*}{$\begin{array}{l}\operatorname{Exp}(B \\
)\end{array}$} & \multicolumn{2}{|c|}{$\begin{array}{l}\text { 95\% C.I.for } \\
\text { EXP(B) }\end{array}$} \\
\hline & & & & & & & Lower & Upper \\
\hline $\begin{array}{l}\text { Skor_Pengetahua } \\
\mathrm{n}\end{array}$ & 0,501 & 0,140 & 12,885 & 1 & $\begin{array}{l}0,00 \\
0\end{array}$ & 1,650 & 1,255 & 2,169 \\
\hline $\begin{array}{l}\text { Rata_Rata_VitB1 } \\
\text { - }\end{array}$ & 0,715 & 0,216 & 10,956 & 1 & $\begin{array}{l}0,00 \\
1\end{array}$ & 2,045 & 1,339 & 3,122 \\
\hline Constant & -4.590 & 1,151 & 15,903 & 1 & $\begin{array}{l}0,00 \\
0\end{array}$ & 0,010 & & \\
\hline
\end{tabular}


pada tahun 2014 menunjukkan angka 18,4 \%. Hal ini dapat terjadi karena masih kurangnya pengetahuan gizi remaja khususnya tentang masalah anemia (Tabel 2). Disamping itu, program pemerintah yang sudah mensosialisasikan agar remaja puteri minum tablet zat besi, belum sepenuhnya terlaksana sesuai harapan. Masih kurangnya pengetahuan gizi remaja, berdampak pada rendahnya tindakan dalam memilih makanan yang merupakan sumber zat besi ataupun bahan makanan yang banyak mengandung senyawa seperti vitamin $\mathrm{C}$, vitamin B12 dan asam Folat yang dapat meningkatkan absorsi terhadap zat besi yang terkandung dalam bahan makanan yang dikonsumsi (Almatsier, 2016). Hal ini dapat diketahui dari hasil analisis terhadap data food recall pada Tabel 3 yang menujukkan bahwa asupan protein, vitamin $\mathrm{C}$ dan asam folat remaja puteri SMP umumnya masih kurang baik, walaupun asupan vitamin B12 ummnya sudah tergolong dalam kategori baik.

Vitamin $\mathrm{C}$ umumnya banyak terdapat di dalam pangan nabati, yaitu sayur dan buah terutama yang asam, seperti jeruk, nenas, rambutan, jambu, dan pepaya. Vitamin $\mathrm{C}$ juga banyak terdapat di dalam sayuran daun-daunan. Vitamin B9 atau asam folat adalah komponen kristal berwarna kuning yang larut dalam air (Piliang dkk, 2006). Sebanyak 50\%-95\% folat hilang karena pemasakan dan pengolahan, padahal Asam folat dibutuhkan untuk pembentukan sel darah merah dan sel darah putih dalam sumsum tulang belakang serta proses pematangannya. Vitamin $\mathrm{B}_{12}$ ditemukan dalam bahan makanan asal protein hewani. Susu segar, telur, ikan, keju, dan daging merupakan bahan makanan yang cukup mengandung vitamin $\mathrm{B}_{12}$. Kecenderungan rusaknya vitamin $\mathrm{C}$ dan asam folat dalam proses pengolahan, menjadi alah satu penyebab cenderung tidak dapat terpenuhinya kebutuhan remaja akan vitamn $\mathrm{C}$ dan asam folat. Di sisi lain, kebutuhan akan vitamin B12 yang relatif kecil $(2,4 \mathrm{mcg} / \mathrm{hari})$ dapat terpenuhi pada sumber bahan makanan yang cenderung lebih disukai oleh remaja sekarang ini seperti daging sapi, keju dan susu (Almatsier, 2016).

Adapun status gizi remaja puteri, menunjukkan data yang penting untuk disikapi dan diperhatikan karena ternyata hanya 38,0\% remaja puteri yang memiliki status gizi normal, sedangkan selebihnya memiliki status gizi kurang $(48,2 \%)$ dan status gizi lebih (gemuk dan obesitas) sebanyak $14,7 \%$. Kondisi ini tentunya tudak sehat serta mengkhawatirkan untuk masa depan Indonesia, mengingat para remaja puteri adalah calon ibu yang diharapkan dapat senantiasa sehat untuk dapat melahirkan calon generasi penerus yang sehat. Hal ini juga tentunya berkaitan dengan kurangnya pengetahuan remaja puteri tentang gizi dan kesehatan sehingga implementasi dalam pola makan tidak sesuai dengan kebutuhan gizi dan anjuran kesehatan. Masa remaja juga merupakan tahapan kritis kehidupan, sehingga periode tersebut dikategorikan sebagai kelompok rawan, dan mempunyai risiko kesehatan tinggi serta banyak kasus kesehatan saat dewasa ditentukan oleh kebiasaan hidup sehat sejak usia remaja (Briawan, 2014; Fikawati, 2017).

Hasil analisis statistik menggunakan analisis bivariat Chi-square dan regresi logistik menunjukkan terdapatnya hubungan yang signifikan antara beberapa variabel dengan kejadian anemia (Tabel 5). Analisis multivariat dengan regresi Logistik Berganda, menunjukkan bahwa faktor dominan yang memengaruhi kejadian anemia pada remaja puteri SMP adalah rata-rata asupan vitamin B12 serta tingkat pengetahuan gizinya. Hasil analisis ini menyimpulkan bahwa asupan vitamin B12 yang baik 2,04 kali dan tingkat pengetahuan yang baik 1,67 kali dapat menghindarkan remaja puteri dari kejadian anemia.

\section{KESIMPULAN DAN SARAN}

Hasil penelitian menunjukkan tidak terdapatnya hubungan asupan protein dengan kadar $\mathrm{Hb}$ remaja. Hal ini dapat disebabkan pola makan yang masih belum baik dan umumnya pemenuhan protein berasal dari sumber makanan yang sama yang dibeli di sekolah atau makanan yang tersaji di luar seko;ah. Kurangnya pengetahuan tetap menjadi salah satu penyebab masih tingginya jumlah remaja yang belum mampu memenuhi kebutuhan proteinnya. Adapun vitamin $\mathrm{C}$ dan asam folat yang merupakan zat gizi yang dapat meningkatkan penyerapan zat besi yang umumnya masih dalam kategori kurang baik. Keadaan ini juga disebabkan kurangnya pengetahuan remaja puteri akan sumber makanan dan pentingnya senyawa tersebut, sehingga tidak memperhatikannya dalam memilih makanan yang akan dikonsumsi. Oleh karena itu, remaja putri tetap harus ditingkatkan pengetahuan gizi dan kesehatanya, mereka dapat memahmi kebutuhan gizi yang harus dipenuhi serta mampu memilih berbagai bahan makanan yang dapat menyumbangkan zat gizi sesuai kebutuhan. 


\section{Vol. 15 No. 1 Januari - April 2020}

Hasil penelitian menyarankan untuk memberikan penyuluhan secara berkala yang dapat diberikan sebagai mata pelajaran ekstrakurikuler sehingga akan dapat meningkatkan pengetahuan gizi bagi remaja puteri mengenai gizi dan kesehatan. Selanjutnya hal ini diharapkan akan dapat menambah keperdulian mereka untuk memenuhi kebutuhan gizi mereka melalui perbaikan pola konsumsi makanan sehingga dapat menghindarkan remaja puteri dari kejadian anemia. Hal ini sesuai hasil penelitian Nasution (2016), bahwa peningkatan pengetahuan signifikan dapat merubah pola konsumsi makanan dan asupan gizi pada kelompok wanita usis subur.

\section{DAFTAR PUSTAKA}

Adriani, Merryana dan Bambang Wijatmadi. 2012. Pengantar Gizi Masyarakat. Kencana Prenada Media Group. Jakarta.

Almatsier, Sunita. 2016. Prinsip Dasar Ilmu Gizi. PT Gramedia Pustaka Utama. Jakarta.

Arisman, MB.2010. Gizi dalam Daur kehiupan Buku Ajar Ilmu Gizi II. EGC. Jakarta.

Aryani, Ratna. 2012. Kesehatan Remaja Problem dan Solusinya. Salemba Medika. Jakarta.

Kesehatan Remaja Problem dan Solusinya. Salemba Medika. Jakarta

Briawan, Dodik. 2014. Anemia Masalah Gizi Pada Remaja Wanita. Penerbit Buku Kedokteran EGC. Jakarta

Dewi M, A. Wawan, 2018. Pengetahuan, Sikap, Dan Perilaku Manusia. Yogjakarta

Fikawati, S., Ahmad Syafiq., Arinda Veratamala.2017. Gizi Anak dan Remaja. PT Rajagrafindo Persada.Depok..

Kemenkes RI. 2013. Laporan Hasil Riset Kesehatan Dasar (Riskesdas) Indonesia tahun 2013. Badan Penelitian dan Pengembangan Kesehatan Kemenkes RI. Jakarta.

Kemenkes RI. 2015. Profil Kesehatan Indonesia tahun 2014. Kemenkes RI. Jakarta.

Nasution, Zuraidah., Sirojuzilam., Zulhaida Lubis., Erna Mutiara. 2016. The Effect Of Empowerment Upon The Food Intake and The Hemoglobin Level Of Pregnant Women In Coastal Areas. Ponte Journal. 10(10).

Notoatmodjo, S. 2010. Promosi Kesehatan: Teori dan Aplikasi. Jakarta: Rineka Cipta.

Rachmat, Mochamad. 2016. Metodologi Penelitian Gizi dan Kesehatan. EGC Penerbit Buku Kedokteran. Jakarta.
Saryono. 2013. Kumpulan Instrumen Penelitian Kesehatan. Nuha Medika. Malang.

Sirajuddin, Mustamin., Nadimin., Suriani. 2014. Survei Konsumsi Pangan. Penerbit Buku Kedokteran EGC. Jakarta

Supariasa, Bakri, dan Fajar. 2016. Penilaian Status Gizi. Penerbit Buku Kedokteran EGC. Jakarta.

Wawan dan Dewi. 2010. Teori dan Pengukuran Pengetahuan Sikap dan Prilaku Manusia. Yogyakarta: Nuha Medika

World Health Organization. 2014. Global Nnutrition Ttargets 2015 Aanaemia Policy Brief.

World Health Organization. Global Anemia Prevalence and Nnumber of Individuals Affected. 2008. 